\title{
What drives Bitcoin's price crash risk?
}

\author{
Article
}

Accepted Version

Creative Commons: Attribution-Noncommercial-No Derivative Works 4.0

Kalyvas, A., Papakyriakou, P., Sakkas, A. and Urquhart, A. (2020) What drives Bitcoin's price crash risk? Economics Letters, 191. 108777. ISSN 0165-1765 doi: https://doi.org/10.1016/j.econlet.2019.108777 Available at https://centaur.reading.ac.uk/86923/

It is advisable to refer to the publisher's version if you intend to cite from the work. See Guidance on citing.

To link to this article DOI: http://dx.doi.org/10.1016/j.econlet.2019.108777

Publisher: Elsevier

All outputs in CentAUR are protected by Intellectual Property Rights law, including copyright law. Copyright and IPR is retained by the creators or other copyright holders. Terms and conditions for use of this material are defined in the End User Agreement.

\section{www.reading.ac.uk/centaur}

\section{CentAUR}

Central Archive at the University of Reading

Reading's research outputs online 


\title{
What drives Bitcoin's price crash risk?
}

\begin{abstract}
We examine the association of the Bitcoin price crash risk with economic uncertainty and behavioral factors. We show that economic uncertainty displays a negative and significant association with Bitcoin price crash risk, indicating that when economic uncertainty is high, the crash risk of Bitcoin is low. We also find that behavioral factors have a weak association with Bitcoin crash risk. Our results suggest that investors can hedge economic uncertainty by investing in Bitcoin.
\end{abstract}

Keywords: Bitcoin, Crash Risk, EPU, VIX, VSTOXX, Behavioral Factors 


\section{Introduction}

Bitcoin has attracted significant interest from investors, the media, and the academic literature. Recent research shows that Bitcoin exhibits hedging properties against economic uncertainty (Bouri et al., 2017), can be a hedge and safe-haven against currencies (Urquhart and Zhang, 2019), and can be a hedge during specific market states (Selmi et al., 2018). Further, the inclusion of Bitcoin in investment portfolios has been shown to offer substantial diversification benefits and to improve risk-adjusted returns (Briere et al., 2015). However, Bitcoin has been characterized by large price volatility and bubble-like behavior (Fry and Cheah, 2016; Corbet et al., 2018; Fry, 2018; Chaim and Laurini, 2019; Katsiampa et al., 2019). Therefore, it is imperative to understand the drivers behind the crash risk for this popular cryptocurrency as it may have important effects on the performance and relationship of Bitcoin with other financial assets.

[Please insert Figure 1 here]

We investigate the drivers behind Bitcoin price crash risk by studying the relationship between Bitcoin crash risk and two distinct factors - i.e. economic uncertainty and behavioral factors. We find robust evidence that Bitcoin price crash risk has a negative and significant relationship with the uncertainty factors while the behavioral factors display a weaker association with Bitcoin price crash risk. Our findings indicate that Bitcoin may possess hedging properties against economic uncertainty; therefore, it may be beneficial for investors to consider this cryptocurrency as an investment when economic uncertainty is high. Furthermore, these findings contribute to the academic debate on whether macro factors, such as economic uncertainty, play a role in the behavior of the price of cryptocurrencies (Liu and Tsyvinski, 2018).

The rest of this paper is organized as follows. The next section presents the data and methodology, while section 3 reports the empirical findings. Section 4 summarizes the findings and provides conclusions.

\section{Data and Methodology}

We employ tick-level data of Bitstamp as our Bitcoin price, sourced from

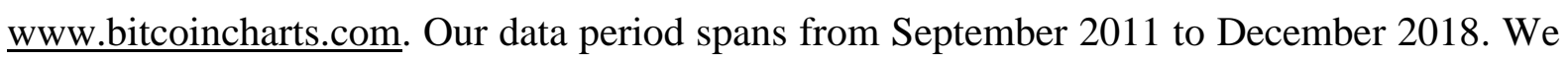


choose Bitstamp as it is one of the most popular and liquid Bitcoin exchanges (Shen et al., 2019). ${ }^{1}$

We adopt two crash-risk measures from the stock price crash literature, both proposed by Chen et al. (2001). The first is the negative coefficient of skewness of the intra-daily returns of Bitcoin (NCSKEW). This measure is most appropriate when returns are asymmetric as manifested by negative skewness and this fits the Bitcoin case because several studies show that its returns are negatively skewed (see, e.g., Urquhart, 2016; Chaim and Laurini, 2019). Further, Fry and Cheah (2016) provide evidence of negative bubbles in the cryptocurrency markets while in Fry's (2018) theoretical model, absence of central regulation allows for a collapse in cryptocurrency prices.

Hence, we calculate Bitcoin price crash risk on a daily basis as the negative of the third moment of one-minute intra-daily Bitcoin returns, divided by the cubed standard deviation.

$$
N \operatorname{NSKEW} W_{t}=\frac{-\left(n(n-1)^{\frac{3}{2}} \sum R_{t}^{3}\right.}{\left((n-1)(n-2)\left(\sum R_{t}^{2}\right)^{\frac{3}{2}}\right)} .
$$

The element $n$ denotes the number of one-minute Bitcoin returns, whereas " $R$ " denotes the intra-day Bitcoin return.

The second measure (DUVOL) is less sensitive to extreme returns, as it does not take into account the third moment. DUVOL is calculated as follows. ${ }^{2}$

$$
D U V O L_{t}=\log \left\{\frac{\left(n_{u}-1\right) \sum_{D O W N} R_{t}^{2}}{\left(n_{d}-1\right) \sum_{U P} R_{t}^{2}}\right\}
$$

The elements $n_{u}$ and $n_{d}$ denote the number of up- and down-minute returns within a day, respectively. Specifically, we separate all one-minute returns above (below) the mean of the return each day and consider each day as an "up" ("down") day. We then calculate the standard deviation for the up and down days separately. Finally, we calculate the log ratio of the standard deviation of the down days to the standard deviation of the up days.

We employ two uncertainty factors to test their effect on the Bitcoin price crash risk. The first is the implied volatility index (VIX), which is a measure of uncertainty in the US equity

\footnotetext{
${ }^{1}$ Intraday data before September 2011 are very illiquid.

2 The correlation (0.70) between the two crash risk measures is fairly high. This is comparable to and consistent with the stock price crash risk literature (see, e.g., Callen and Fang, 2015).
} 
market. The VIX index is an estimate of the expectation of the market near-term volatility based on stock index option prices. We source this variable from the FRED database of the Federal Reserve Bank of St Louis. The VIX index is available on a daily basis, excluding nontrading days (e.g., weekends). The second uncertainty factor is the US economic policy uncertainty (EPU) news-based index of Baker et al. $(2016)^{3}$ which captures the overall level of US economic policy uncertainty and is available on a daily basis (seven days a week). We use the natural log of VIX and EPU to control for excess skewness and excess kurtosis. We follow other studies in the finance and Bitcoin literature (e.g., Mueller et al., 2017; Wu et al., 2019) and use US-based measures of uncertainty because of the dominant role of the US economy in the global financial markets. We also use the equivalent of VIX for the European markets (VSTOXX), sourced from Thomson Reuters Datastream, because the Bitstamp exchange has a strong presence in Europe (Makarov and Schoar, 2019).

We further consider the Thomson Reuters Marketpsych Indices (TRMI) to test whether behavioral factors can explain the crash risk of Bitcoin. The TRMI are available at the country level, on a daily basis, and seven days per week. Several indices make up the TRMI family such as the Sentiment, Buzz, Optimism, Trust, Fear and Joy, among others. For our study, we consider Sentiment, Buzz and Fear. The Sentiment variable quantifies the content of news stories on a continuous scale between -1 and +1 , from the most negative to the most positive. Buzz is based on the frequency (number) of news stories and can range from zero to (theoretically) infinity. In our estimations, we use the natural logarithm of the Buzz variable. Fear quantifies the level of fear and ranges from zero to unity, with higher values indicating higher levels of fear. ${ }^{4}$ We construct GDP-weighted averages of Sentiment, Buzz, and Fear by using the GDP data of the G20 economies that we source from the World Development Indicators of the World Bank.

Finally, we follow the crash risk literature (e.g., Chang et al., 2017; Jia, 2018) and winsorize all variables at the $1^{\text {st }}$ and $99^{\text {th }}$ percentiles. Table 1 reports descriptive statistics. We observe a strong variation in each variable, thereby enabling a robust examination of the impact of each variable on Bitcoin crash risk.

[Please insert Table 1 here]

\footnotetext{
${ }^{3}$ Available at www.policyuncertainty.com.

${ }^{4}$ For further information on the TRMI indices, visit https://www.marketpsych.com.
} 
We employ both univariate and multivariate regression models. We define the full multivariate specification as NCSKEW or DUVOL $=f(x, z)$ where $x$ and $\mathrm{z}$ denote the vectors of the uncertainty factors and the behavioral factors, respectively.

\section{Empirical Findings}

In Table 2 (Panel A), we report the baseline univariate results where the first measure of Bitcoin price crash risk, $N C S K E W$, is regressed on economic uncertainty and behavioral variables. We show that each of the coefficients of the economic uncertainty variables is negative and statistically significant at the $1 \%$ level, indicating that when economic uncertainty is high the price crash risk in Bitcoin is low. We also show that Sentiment has a weakly significant and positive relationship with crash risk. However, we do not find a significant association between Buzz, Fear, and our measure of crash risk. Thus, our univariate results suggest that economic uncertainty is negatively related to crash risk, indicating that Bitcoin may be an appropriate hedging instrument for investors during periods of high economic uncertainty.

\section{[Please insert Table 2 here]}

In Table 2 (Panel B), we augment the univariate models with the rest of the variables of interest and control for the Bitcoin trading volume. We find that economic uncertainty is significantly negatively related to crash risk, suggesting that investors can hedge high economic uncertainty by investing in Bitcoin. A one-standard-deviation increase in EPU decreases Bitcoin price crash risk by $0.545 \times 0.089=0.049$; similarly, a one-standard-deviation increase in VIX (VSTOXX) decreases Bitcoin price crash risk by $0.269 \times 0.278=0.075$ $(0.281 \times 0.122=0.034)$. The stronger statistical significance of VIX in comparison with its European counterpart, VSTOXX, suggests that uncertainty in the US equity market is particularly important for the Bitcoin market (Borri, 2019). Further, we find a positive and significant association between the Bitcoin price crash risk and the Sentiment variable. As such, we advise investors to consider alternative investments in periods of high market sentiment. $^{5}$

To examine the robustness of the above findings, we further consider the results from models that use our second measure of Bitcoin price crash risk, DUVOL as the dependent

\footnotetext{
${ }^{5}$ We also perform 1-, 2- and 3-year rolling regressions to examine the stability of our results over time and the results are qualitatively similar to the full sample results. These results are not reported due to space constraints but are available upon request from the corresponding author.
} 
variable, which does not depend on the third moment. ${ }^{6}$ Table 3 reports the results from these specifications. These findings are consistent with those in Table 2 in showing a negative and significant relationship between Bitcoin crash risk and uncertainty factors.

\section{[Please insert Table 3 here]}

\section{Summary and Conclusions}

Bitcoin is the most popular among all cryptocurrencies, having received increased levels of attention from the media and investors alike in recent years. However, given the substantial volatility of the asset and associated periods of extreme bubbles, investing in it entails high risk. Our results suggest that the crash risk of Bitcoin price displays a negative and significant relationship with economic uncertainty factors. Therefore, investors could consider using Bitcoin as a hedging instrument in periods of high economic uncertainty. Finally, we find a weak correlation between the price crash risk of Bitcoin and behavioral factors, such as the market Sentiment and Buzz.

\footnotetext{
${ }^{6}$ We thank an anonymous referee for suggesting using a measure of crash risk that does not rely on the third moment and, hence, is less likely to be exacerbated by a few extreme data points.
} 


\section{References}

Baker, S. R., Bloom, N., \& Davis, S. J. (2016). Measuring Economic Policy Uncertainty. Quarterly Journal of Economics, 131(4), 1593-1636.

Borri, N. (2019). Conditional tail-risk in cryptocurrency markets. Journal of Empirical Finance, 50, 1-19.

Bouri, E., Gupta, R., Tiwari, A. K., \& Roubaud, D. (2017). Does Bitcoin hedge global uncertainty? Evidence from wavelet-based quantile-in-quantile regressions. Finance Research Letters, 23, 87-95.

Briere, M., Oosterlinck, K., \& Szafarz, A. (2015). Virtual currency, tangible return: Portfolio diversification with bitcoin. Journal of Asset Management, 16(6), 365-373.

Callen, J. L., \& Fang, X. (2015). Religion and Stock Price Crash Risk. Journal of Financial and Quantitative Analysis, 50(1-2), 169-195.

Chaim, P., \& Laurini, M. (2019). Is Bitcoin a bubble? Physica A: Statistical Mechanics and its Applications, 517(C), 222-232.

Chang, X., Chen, Y., \& Zolotoy, L. (2017). Stock Liquidity and Stock Price Crash Risk. Journal of Financial and Quantitative Analysis, 52(4), 1605-1637.

Chen, J., Hong, H., \& Stein, J. C. (2001). Forecasting crashes: trading volume, past returns, and conditional skewness in stock prices. Journal of Financial Economics, 61(3), 345381.

Corbet, S., Lucey, B., \& Yarovaya, L. (2018). Datestamping the Bitcoin and Ethereum bubbles. Finance Research Letters, 26, 81-88.

Fry, J. (2018). Booms, busts and heavy-tails: The story of Bitcoin and cryptocurrency markets? Economics Letters, 171, 225-229.

Fry, J., \& Cheah, E.-T. (2016). Negative bubbles and shocks in cryptocurrency markets. International Review of Financial Analysis, 47, 343-352.

Jia, N. (2018). Corporate innovation strategy and stock price crash risk. Journal of Corporate Finance, 53, 155-173.

Katsiampa, P., Corbet, S., \& Lucey, B. (2019). High frequency volatility co-movements in cryptocurrency markets. Journal of International Financial Markets, Institutions and Money, 62, 35-52.

Liu, Y., \& Tsyvinski, A. (2018). Risks and returns of cryptocurrency. NBER Working Paper No. 24877.

Makarov, I., \& Schoar, A. (2019). Trading and arbitrage in cryptocurrency markets. Journal of Financial Economics, Forthcoming.

Mueller, P., Stathopoulos, A., \& Vedolin, A. (2017). International correlation risk. Journal of Financial Economics, 126(2), 270-299.

Newey, W. K., \& West, K. D. (1987). A simple positive semi-definite, heteroskedasticity and autocorrelation consistent covariance matrix. Econometrica, 55(3), 703-708.

Selmi, R., Mensi, W., Hammoudeh, S., \& Bouoiyour, J. (2018). Is Bitcoin a hedge, a safe haven or a diversifier for oil price movements? A comparison with gold. Energy Economics, 74, 787-801.

Shen, D., Urquhart, A., \& Wang, P. (2019). Does twitter predict Bitcoin? Economics Letters, $174,118-122$.

Urquhart, A. (2016). The inefficiency of Bitcoin. Economics Letters, 148, 80-82.

Urquhart, A., \& Zhang, H. (2019). Is Bitcoin a hedge or safe haven for currencies? An intraday analysis. International Review of Financial Analysis, 63, 49-57.

Wu, S., Tong, M., Yang, Z., \& Derbali, A. (2019). Does gold or Bitcoin hedge economic policy uncertainty? Finance Research Letters, 31, 171-178. 
Table 1. Summary Statistics

This table presents the summary statistics of the two measures of Bitcoin crash risk(NCSKEW,DUVOL), the implied volatility index (VIX), the economic policy uncertainty $(E P U)$, and the Sentiment, Buzz and Fear TRMI measures. Mean, Standard deviation (Sd.), maximum (max), minimum (min), kurtosis (Kurt) and Skewness (Skew) are on a daily basis. Note that we use the natural log of the uncertainty and sentiment measures and all variables are winsorized at the $1^{\text {st }}$ and $99^{\text {th }}$ percentiles.

\begin{tabular}{|c|c|c|c|c|c|c|c|c|}
\hline & NCSKEW & DUVOL & $V I X$ & VSTOXX & $E P U$ & SENTIMENT & $B U Z Z$ & $F E A R$ \\
\hline Mean & 0.082 & -0.039 & 2.718 & 2.987 & 4.446 & -0.060 & 12.345 & 0.008 \\
\hline $\mathrm{Sd}$. & 0.763 & 0.310 & 0.269 & 0.281 & 0.545 & 0.023 & 0.437 & 0.001 \\
\hline Max & 3.097 & 1.271 & 3.549 & 3.745 & 5.737 & -0.008 & 12.938 & 0.011 \\
\hline Min & -2.718 & -1.440 & 2.260 & 2.460 & 3.099 & -0.111 & 11.310 & 0.006 \\
\hline Skew & 0.253 & -0.493 & 0.863 & 0.424 & -0.022 & 0.053 & -0.757 & 0.639 \\
\hline Kurt & 7.480 & 11.145 & 3.675 & 2.849 & 2.714 & 2.577 & 2.326 & 3.329 \\
\hline
\end{tabular}

Fig. 1. Time-series graph of the Bitcoin price during the sample period utilized in this study.

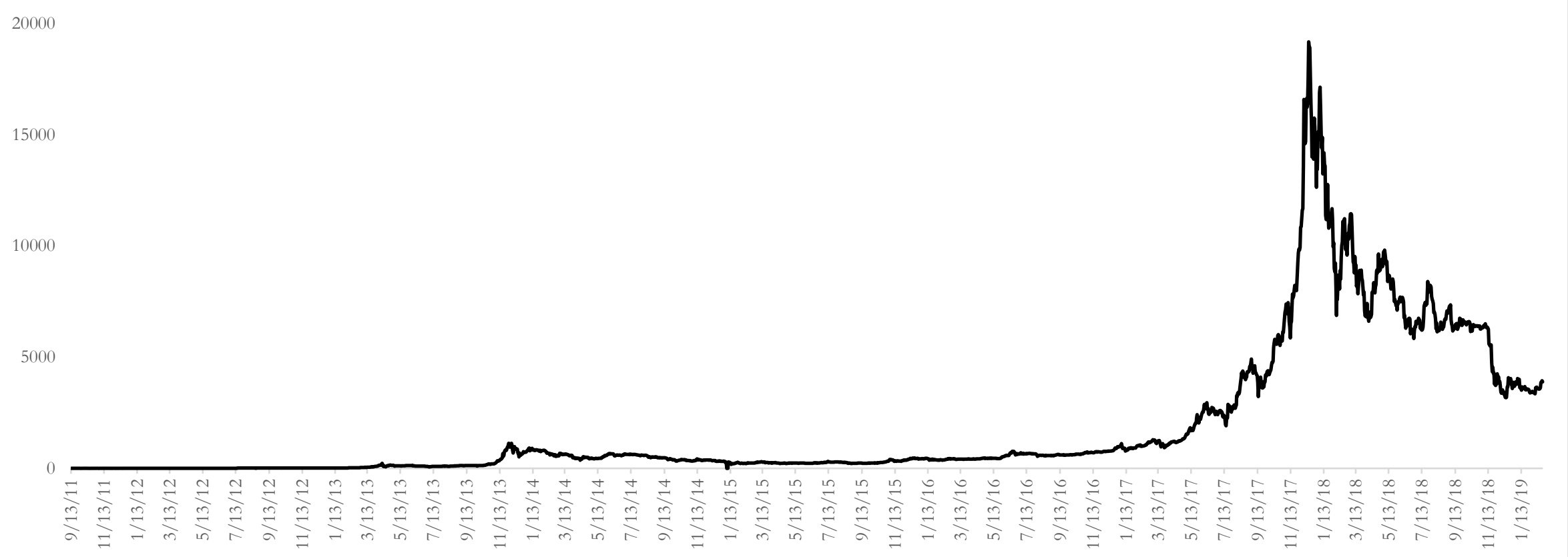




\begin{tabular}{|c|c|c|c|c|c|c|}
\hline $\begin{array}{l}\text { This table prese } \\
N C S K E W \text { agair } \\
\text { and the Sentime } \\
\text { standard errors } \\
\text { respectively. } \\
\text { we use the natu } \\
99^{\text {th }} \text { percentiles. }\end{array}$ & $\begin{array}{l}\text { univariate (I } \\
\text { implied vola } \\
\text { zz and Fear T } \\
\text { ported in par } \\
\text { notes the adju } \\
\text { of the uncer }\end{array}$ & $\begin{array}{l}\text { nel A) and } \mathrm{m} \\
\text { ity indices } \\
\text { MI measures } \\
\text { theses. } * * * \text {, } \\
\text { ed R-squarec } \\
\text { inty and sent }\end{array}$ & $\begin{array}{l}\text { tivariate regr } \\
I X \text { and } V S T \\
\text { Ne also contr } \\
\text { and } * \text { indic } \\
\text { nd p-value st } \\
\text { nent measure }\end{array}$ & $\begin{array}{l}\text { ns (Panel B) } \\
\text {, the econom } \\
\text { the volume. } \\
\text { gnificance at } \\
\text { for the p-val } \\
\text { all variables }\end{array}$ & $\begin{array}{l}\text { e Bitcoin pric } \\
\text { olicy uncerta } \\
\text { vey West (19 } \\
1 \%, 5 \% \text { and } \\
\text { f the F-statist } \\
\text { winsorized a }\end{array}$ & $\begin{array}{l}\text { crash risk } \\
\text { nty }(E P U) \text {, } \\
7) \text { adjusted } \\
10 \% \text { levels } \\
\text {. Note that } \\
\text { the } 1^{\text {st }} \text { and }\end{array}$ \\
\hline & & el A. Univar & te Regressio & & & \\
\hline Variables & $N_{C S K E W_{t}}$ & $N_{C S K E W_{t}}$ & $N C S K E W_{t}$ & $N_{C S K E W_{t}}$ & $N_{C S K E W_{t}}$ & $\overline{N C S K E W_{t}}$ \\
\hline$V I X_{t}$ & $\begin{array}{c}-0.283 * * * \\
(0.0782)\end{array}$ & & & & & \\
\hline VSTOXX & & $\begin{array}{c}-0.156 * * \\
(0.0683)\end{array}$ & & & & \\
\hline$E P U_{t}$ & & & $\begin{array}{c}-0.0943 * * * \\
(0.0313)\end{array}$ & & & \\
\hline SENTIMENT $T_{t}$ & & & & $\begin{array}{l}1.522^{*} \\
(0.801)\end{array}$ & & \\
\hline$B U Z Z_{t}$ & & & & & $\begin{array}{c}0.0278 \\
(0.0354)\end{array}$ & \\
\hline$F E A R_{t}$ & & & & & & $\begin{array}{c}-21.79 \\
(18.450)\end{array}$ \\
\hline Constant & $\begin{array}{c}0.869 * * * \\
(0.212)\end{array}$ & $\begin{array}{c}0.564 * * * \\
(0.205)\end{array}$ & $\begin{array}{c}0.504 * * * \\
(0.136)\end{array}$ & $\begin{array}{c}0.173 * * * \\
(0.0502)\end{array}$ & $\begin{array}{l}-0.261 \\
(0.433)\end{array}$ & $\begin{array}{l}0.256^{*} \\
(0.149) \\
\end{array}$ \\
\hline$R_{a d j}^{2}$ & 0.0083 & 0.0024 & 0.0040 & 0.0017 & -0.0001 & 0.0003 \\
\hline$p$-value & $(0.0001)$ & $(0.0181)$ & $(0.0007)$ & $(0.0201)$ & $(0.4146)$ & $(0.1730)$ \\
\hline Observations & 1,837 & 1,906 & 2,656 & 2,633 & 2,633 & 2,633 \\
\hline & Pal & B. Multiva & te Regressi & & & \\
\hline Variables & $N_{C S K E} W_{t}$ & $N_{C S K E W_{t}}$ & $N_{C S K E} W_{t}$ & $N C S K E W_{t}$ & $N_{C S K E W_{t}}$ & \\
\hline$V I X_{t}$ & $\begin{array}{c}-0.278 * * * \\
(0.0826)\end{array}$ & & & $\begin{array}{c}-0.232 * * * \\
(0.0877)\end{array}$ & & \\
\hline$V S T O X X_{t}$ & & $\begin{array}{l}-0.122 * \\
(0.0718)\end{array}$ & & & $\begin{array}{l}-0.0539 \\
(0.0760)\end{array}$ & \\
\hline$E P U_{t}$ & & & $\begin{array}{c}-0.0893 * * * \\
(0.0324)\end{array}$ & $\begin{array}{l}-0.0381 \\
(0.0396)\end{array}$ & $\begin{array}{l}-0.0601 \\
(0.0388)\end{array}$ & \\
\hline SENTIMENT $T_{t}$ & $\begin{array}{l}2.046^{*} \\
(1.140)\end{array}$ & $\begin{array}{l}2.157^{*} \\
(1.150)\end{array}$ & $\begin{array}{c}1.386 \\
(1.014)\end{array}$ & $\begin{array}{l}2.140^{*} \\
(1.137)\end{array}$ & $\begin{array}{c}2.233^{* *} \\
(1.138)\end{array}$ & \\
\hline$B U Z Z_{t}$ & $\begin{array}{l}-0.0975 \\
(0.104)\end{array}$ & $\begin{array}{l}-0.0987 \\
(0.0855)\end{array}$ & $\begin{array}{l}-0.0157 \\
(0.0414)\end{array}$ & $\begin{array}{r}-0.0521 \\
(0.103)\end{array}$ & $\begin{array}{l}-0.0560 \\
(0.0851)\end{array}$ & \\
\hline$F E A R_{t}$ & $\begin{array}{c}12.34 \\
(26.21)\end{array}$ & $\begin{array}{c}2.052 \\
(25.05)\end{array}$ & $\begin{array}{l}-1.776 \\
(20.50)\end{array}$ & $\begin{array}{c}12.64 \\
(26.10)\end{array}$ & $\begin{array}{l}2.336 \\
(24.75)\end{array}$ & \\
\hline$V O L U M E_{t}$ & & & & $\begin{array}{c}-0.0113 \\
(0.00867)\end{array}$ & $\begin{array}{c}-0.0175^{* *} \\
(0.00877)\end{array}$ & \\
\hline Constant & $\begin{array}{c}2.092 \\
(1.294)\end{array}$ & $\begin{array}{l}1.800^{*} \\
(1.064)\end{array}$ & $\begin{array}{c}0.771 \\
(0.562)\end{array}$ & $\begin{array}{c}1.548 \\
(1.317)\end{array}$ & $\begin{array}{c}1.300 \\
(1.093)\end{array}$ & \\
\hline$R_{a d j}^{2}$ & 0.0107 & 0.0038 & 0.0046 & 0.0116 & 0.0078 & \\
\hline p-value & $(0.0001)$ & $(0.0241)$ & $(0.0029)$ & $(0.0001)$ & $(0.0021)$ & \\
\hline Observations & 1,822 & 1,889 & 2,633 & 1,822 & 1,889 & \\
\hline
\end{tabular}




\section{Table 3.}

The relationship between economic uncertainty, behavioural factors and Bitcoin price crash risk (DUVOL)

This table presents the univariate (Panel A) and multivariate regressions (Panel B) of the Bitcoin price crash risk DUVOL against the implied volatility indices (VIX and VSTOXX), the economic policy uncertainty (EPU), and the Sentiment, Buzz and Fear TRMI measures. We also control for the volume. Newey West (1987) adjusted standard errors are reported in parentheses. $* * *, * *$ and $*$ indicate significance at the $1 \%, 5 \%$ and $10 \%$ levels, respectively. $R_{a d j}^{2}$ denotes the adjusted R-squared and p-value stands for the p-value of the F-statistic. Note that we use the natural $\log$ of the uncertainty and sentiment measures and all variables are winsorized at the $1^{\text {st }}$ and $99^{\text {th }}$ percentiles.

\begin{tabular}{|c|c|c|c|c|c|c|}
\hline \multicolumn{7}{|c|}{ Panel A. Univariate Regressions } \\
\hline Variables & $D U V O L_{t}$ & $D U V O L_{t}$ & $D U V O L_{t}$ & $D_{U V O L_{t}}$ & $\mathrm{DUVOL}_{t}$ & $D U V O L_{t}$ \\
\hline$V I X_{t}$ & $\begin{array}{c}-0.0890^{* *} \\
(0.0403)\end{array}$ & & & & & \\
\hline $\operatorname{VSTOXX} X_{t}$ & & $\begin{array}{c}-0.0823 * * \\
(0.0368)\end{array}$ & & & & \\
\hline$E P U_{t}$ & & & $\begin{array}{c}-0.0447 * * * \\
(0.0114)\end{array}$ & & & \\
\hline SENTIMENT $T_{t}$ & & & & $\begin{array}{c}0.121 \\
(0.238)\end{array}$ & & \\
\hline$B U Z Z_{t}$ & & & & & $\begin{array}{c}-0.0188 \\
(0.0131)\end{array}$ & \\
\hline$F E A R_{t}$ & & & & & & $\begin{array}{l}-3.479 \\
(7.048)\end{array}$ \\
\hline Constant & $\begin{array}{l}0.203^{*} \\
(0.106) \\
\end{array}$ & $\begin{array}{l}0.205^{*} \\
(0.106) \\
\end{array}$ & $\begin{array}{c}0.160 * * * \\
(0.0479) \\
\end{array}$ & $\begin{array}{c}-0.0314 * * \\
(0.0152) \\
\end{array}$ & $\begin{array}{c}0.194 \\
(0.161) \\
\end{array}$ & $\begin{array}{r}-0.0109 \\
(0.0566) \\
\end{array}$ \\
\hline $\begin{array}{l}R_{\text {adj }}^{2} \\
p \text {-value } \\
\text { Observations }\end{array}$ & $\begin{array}{l}0.0049 \\
(0.0016)\end{array}$ & $\begin{array}{c}0.0046 \\
(0.0018)\end{array}$ & $\begin{array}{c}0.0057 \\
(0.0001)\end{array}$ & $\begin{array}{l}-0.0003 \\
(0.6514)\end{array}$ & $\begin{array}{c}0.0003 \\
(0.1748)\end{array}$ & $\begin{array}{c}-0.0003 \\
(0.5896) \\
2617\end{array}$ \\
\hline \multicolumn{7}{|c|}{ Panel B. Multivariate Regressions } \\
\hline Variables & $D U V O L_{t}$ & $D U V O L_{t}$ & $\mathrm{DUVOL}_{t}$ & $D U V O L_{t}$ & $D U V O L_{t}$ & \\
\hline$V I X_{t}$ & $\begin{array}{l}-0.0800^{*} \\
(0.0425)\end{array}$ & & & $\begin{array}{c}-0.0458 \\
(0.0386)\end{array}$ & & \\
\hline $\operatorname{VSTOXX} X_{t}$ & & $\begin{array}{c}-0.0662^{*} \\
(0.0378)\end{array}$ & & & $\begin{array}{l}-0.0303 \\
(0.0342)\end{array}$ & \\
\hline$E P U_{t}$ & & & $\begin{array}{c}-0.0465 * * * \\
(0.0116)\end{array}$ & $\begin{array}{c}-0.0294 * * \\
(0.0131)\end{array}$ & $\begin{array}{c}-0.0346 * * * \\
(0.0129)\end{array}$ & \\
\hline SENTIMENT $T_{t}$ & $\begin{array}{c}0.399 \\
(0.395)\end{array}$ & $\begin{array}{c}0.468 \\
(0.395)\end{array}$ & $\begin{array}{c}0.281 \\
(0.337)\end{array}$ & $\begin{array}{c}0.469 \\
(0.395)\end{array}$ & $\begin{array}{c}0.506 \\
(0.390)\end{array}$ & \\
\hline$B U Z Z_{t}$ & $\begin{array}{c}-0.0893 * * \\
(0.0397)\end{array}$ & $\begin{array}{c}-0.0662 * * \\
(0.0304)\end{array}$ & $\begin{array}{l}-0.0308^{*} \\
(0.0162)\end{array}$ & $\begin{array}{l}-0.0546 \\
(0.0401)\end{array}$ & $\begin{array}{l}-0.0413 \\
(0.0300)\end{array}$ & \\
\hline$F E A R_{t}$ & $\begin{array}{l}-1.392 \\
(10.09)\end{array}$ & $\begin{array}{l}-2.180 \\
(9.631)\end{array}$ & $\begin{array}{c}0.880 \\
(7.959)\end{array}$ & $\begin{array}{l}-1.170 \\
(9.792)\end{array}$ & $\begin{array}{l}-1.927 \\
(9.241)\end{array}$ & \\
\hline$V O L U M E_{t}$ & & & & $\begin{array}{c}-0.00847 * * \\
(0.00357)\end{array}$ & $\begin{array}{c}-0.00941 * * * \\
(0.00345)\end{array}$ & \\
\hline Constant & $\begin{array}{c}1.335^{* * * *} \\
(0.493)\end{array}$ & $\begin{array}{c}1.032 * * * \\
(0.380)\end{array}$ & $\begin{array}{c}0.557 * * \\
(0.223)\end{array}$ & $\begin{array}{l}0.923^{*} \\
(0.490)\end{array}$ & $\begin{array}{c}0.749 * * \\
(0.372)\end{array}$ & \\
\hline $\begin{array}{l}R_{\text {adj }}^{2} \\
\text { p-value } \\
\text { Observations }\end{array}$ & $\begin{array}{c}0.0067 \\
(0.0028) \\
1,814\end{array}$ & $\begin{array}{c}0.0053 \\
(0.0071) \\
1,880\end{array}$ & $\begin{array}{c}0.0063 \\
(0.0004) \\
2,617\end{array}$ & $\begin{array}{c}0.0126 \\
(0.0001) \\
1,814\end{array}$ & $\begin{array}{c}0.0137 \\
(0.0000) \\
1,880\end{array}$ & \\
\hline
\end{tabular}

